\title{
Indicator-based monitoring and forecasting water deficit and surplus in agriculture in Poland
}

\author{
LESZEK ŁABĘDZKI, BOGDAN BĄK \\ Institute of Technology and Life Sciences, Kuyavian-Pomeranian Research Centre
}

\begin{abstract}
Indicator-based monitoring and forecasting water deficit and surplus in agriculture in Poland. Since 2012, the Institute of Technology and Life Sciences has been conducting national agrometeorological monitoring in rural areas of Poland. Current and forecasted information on the status and impact of water deficit and surplus in selected, representative agricultural ecosystems and potential reduction of crop yield are being provided annually in the period from April to October. The required meteorological data are provided by a network of automatic stations located in 13 regions on the Polish territory. Weather forecasts, necessary to develop predictions of water shortages or surplus in the next 10 and 20 days, come from the meteorological service of MeteoGroup Poland. Results of the monitoring and forecasts are presented as maps, graphs and tables on the website.
\end{abstract}

Key words: agricultural water monitoring, standardized precipitation index - SPI, soil moisture index - SMI, agricultural drought index - $C D I$, crop yield reduction

\section{INTRODUCTION}

Polish agriculture is significantly dependent on rainfall, characterized by high temporal and spatial variability. Crop production is mainly based on water coming from precipitation in the form of soil water retention. Poland is situated in a transitory temperate climate zone. Natural conditions are rather favourable for agriculture, but drought can be the most important risk factor. In extremely dry years (e.g. 1992 and 2000) up to $40 \%$ of the area of the country was affected by drought. The average decrease in crop yield is estimated at $10-40 \%$ in those years as compared to normal years (Łabędzki 2007). In the growing season, during the peak consumption of water by plants, shortages of rainfall are often accompanied by the greatest crop water needs (Mioduszewski et al. 2011). The periods of surplus of rainfall, causing excessive soil moisture conditions, also occur in the climate of Poland but they are rarer than droughts.

Monitoring and early warning help to reduce the impacts and to mitigate the consequences of weather and climate related natural disasters for agricultural production. Transfer of agrometeorological information to farmers can be done in different ways. Meteorological services use different options, such as periodical bulletins published on the Internet and mass media: TV, radio, newspapers. According to Stigter et al. (2010), the agrometeorological services should be simple for their proper assimilation and they must be used frequently to facilitate decision-making and planning. Agrometeorological 
services are often exemplified by agroclimatological characterization, weather forecasting (including agrometeorological forecasting) and other advisories prepared for farmers.

Among the advanced technologies available in the world today, the Internet provides a suitable tool to achieve these goals. According to Maracchi et al. (2002), the advantages of using the Internet to elaborate and disseminate information in the field of agrometeorology products are: fast utilisation of information, interaction with and feedback from the users, immediate display of the information, facilitation of understanding of advice and warnings, an increase in computer use by the farmers, reduction of information production costs, fast upgrading and updating, continuous monitoring of system performances as well as application of multimedia tools (text, graphic, map, figure, audio, video, etc.).

In line with the observed global warming, many agrometeorological services focus on the impact of drought on the agricultural sector and its negative effect on the productivity of crops, leading to reduced yields. The most known is the US Drought Monitor Website which is created in partnership between the National Drought Mitigation Centre at the University of Nebraska-Lincoln, the United States Department of Agriculture and the National Oceanic and Atmospheric Administration. In order to detect, monitor and forecast droughts on a continental scale, the European Commission Joint Research Centre (JRC) is developing the prototype of the European Drought Observatory (EDO). A multidisciplinary set of indicators is used within EDO to constantly monitor the various environ- mental components potentially affected by this hazard (soil, vegetation, etc.) to obtain a comprehensive and updated picture of the situation (Rossi and Niemeyer 2010). In Europe, there are both multinational services (e.g. Drought Management Centre for South-eastern Europe - DMCSEE, MeteoGroup), national services (e.g. Agrarwetter in Germany, Sea and Atmospheric Portuguese Institute in Portugal, Agrometeorologia in Italy, Royal Netherlands Meteorological Institute in the Netherlands, Elaf in the Netherlands - also as a mobile application) and regional agrometeorological services (AgroMeteo Puglia in Italy, Sud Agro Météo in France).

The objective of the paper is the presentation of the methods being used within the nationwide system of monitoring and forecasting water deficit and surplus in agriculture in Poland as well as results of its operational application during 2013.

\section{EXISTING DROUGHT MONITORING SYSTEMS IN POLAND}

In Poland, there have been four different agrometeorological monitoring systems in operation since 2005. The Institute of Meteorology and Water Management (IMGW) runs the "Hydrometeorological drought monitoring and prediction system" called "POSUCH@"(Tokarczyk and Szalińska 2013, http://posucha.angw. pl, accessed 20.01.14). The operational drought hazard assessment includes meteorological and hydrological drought detection, analysis of drought intensity, duration and extension as well as assessment of susceptibility to drought and drought hazard prediction. Operational 
data are obtained from the network of meteorological and hydrological stations equipped with a telemetry facility.

The Institute of Soil Science and Plant Cultivation runs the agricultural drought monitoring system ADMS (Agricultural Drought Monitoring System), (Doroszewski et al. 2008, 2012, www.susza.iung. pulawy.pl, accessed 15.02.14). Meteorological conditions that cause droughts are evaluated by the climatic water balance $(C W B)$. Values of $C W B$ express the difference between precipitation and potential evapotranspiration calculated with the Penman equation. In the system, drought is defined by losses in crop yields of $20 \%$, caused by the occurrence of climatic water balance $(C W B)$ in six subsequent 10-day periods below a defined value for an individual species or groups of cultivated plants as well as the soil category in the period from 1 April to 30 September.

Another system worth mentioning is the regional drought monitoring system called "Wielkopolska region service of agrometeorological information" (WISIA). The service is run by the Agrometeorology Department of the Agricultural University of Poznań, Poland (www. agrometeo.pl, accessed 20.11.2012). The aim of the website is to provide information and agrometeorological forecasts, which form a system of agricultural support decisions to organize daily work on farms in the Wielkopolska region and in neighbouring provinces (Leśny et al. 2007). The Institute of Geodesy and Cartography, Poland, operates a nationwide system of agricultural drought monitoring on the basis of satellite images (Bochenek et al. 2005, Dąbrowska-Zielińska and Ciołkosz 2007). Drought intensity is estimated using the normalized difference vegetation index (NDVI), crop surface temperature $\left(T_{\mathrm{s}}\right)$, temperature condition index $(T C I)$ and vegetation condition index $(V C I)$.

A different system type was the international program called "Partnership for water". Its purpose was water use optimization in agribusinesses in the catchment of the Gasawka river, Poland. Monitoring has been conducted in 2011-2013, by a Dutch water management consultancy company Nelen \& Schuurmans in association with MeteoConsult, an international weather prediction company and the Kuyavian-Pomeranian Research Centre of the Institute of Technology and Life Sciences (ITP). Local farmers were able to check weather and evaporation predictions as well as the specific crop water need by means of the Internet. Especially during droughts, this approach enabled the prevention of harvest loss and sustained the necessary crop yield.

The system "Monitoring meteorological and agricultural drought in the Kujawy region" was developed and operated by the Kuyavian-Pomeranian Research Centre of the Institute of Technology and Life Sciences (ITP) in 2008-2012, in the Kujawy region located in central Poland (Łabędzki and Bąk 2011a, b). This region is the driest region in Poland, where periods of short-or long-term drought spells are very common. Drought monitoring was carried out using a network of automatic stations for measuring agrometeorological and agrohydrological elements. Meteorological drought was monitored using the relative precipitation index $(R P I)$, standardized precipitation index $(S P I)$ and standardized climatic water balance $(S C W B)$. Agricultural drought 
monitoring was carried out using the crop drought index $(C D I)$. The results of the monitoring of meteorological and agricultural droughts were presented on the website of the ITP.

Since 2012, the regional system has been included in the nationwide system of monitoring water deficit and surplus in agriculture in Poland conducted by the Institute of Technology and Life Sciences (ITP). The system has been implemented in 2011-2015, under the activity 1.2 "Monitoring, Predicting of Progress and Risk of Water Deficit and Surplus in the Rural Areas", within the Programme "Standardization and monitoring of environmental projects, agricultural technology and infrastructure solutions for security and sustainable development of agriculture and rural areas" financed by the Polish Ministry of Agriculture and Rural Development.

\section{DESCRIPTION OF WATER DEFICIT AND SURPLUS MONITORING SYSTEM AND THE METHODS OF MONITORING}

The existing nationwide system provides current and forecasted evaluation of water deficit and surplus for agriculture in selected, representative agricultural ecosystems, and estimates the potential reduction of crop yield due to water shortage. Among all operating agrometeorological monitoring systems in Poland, the nationwide system of monitoring and forecasting water deficit and surplus created by the researchers from ITP, has enhanced the module of medium- and long-term forecasting.

Monitoring of water deficit and surplus and their consequences is carried out using an indicator method. Precipitation conditions are monitored using the standardized precipitation index $(S P I)$, soil moisture - soil moisture index $(S M I)$, the deficit of water for crops - crop drought index $(C D I)$ and the potential reduction of yield due to water deficit - yield reduction ratio $(Y R)$. Results of the monitoring and forecasts are presented in the form of maps on the Internet (http://agrometeo.itp.edu.pl).

The system consists of two main modules: a database and a computational module (Fig. 1). The database gathers real-time measured and historical series of meteorological data, crop parameters and soil-water parameters, which are necessary for calculation of the indicators. Forecasted meteorological data are also supplied to this module. In the computational module, modelling and calculations of indices are carried out. Maps of the spatial distribution of calculated indices are generated by the system.

\section{Precipitation conditions}

The evaluation and forecasting of precipitation conditions (water deficit and surplus) are made using the standardized precipitation index $(S P I)$, which is calculated at different time scales. The SPI is a standardized deviation of precipitation in a particular period from the median long-term value of this period (McKee et al. 1993, 1995). The method ensures independence from geographical positions as the index in question is calculated with respect to average precipitation in the same place (Cacciamani et al. 2007).

$S P I$ is calculated for each calendar month at 1-, 2-, 3-, 6-, 12-, 24-, 36- and 48-month time periods using the long-term 


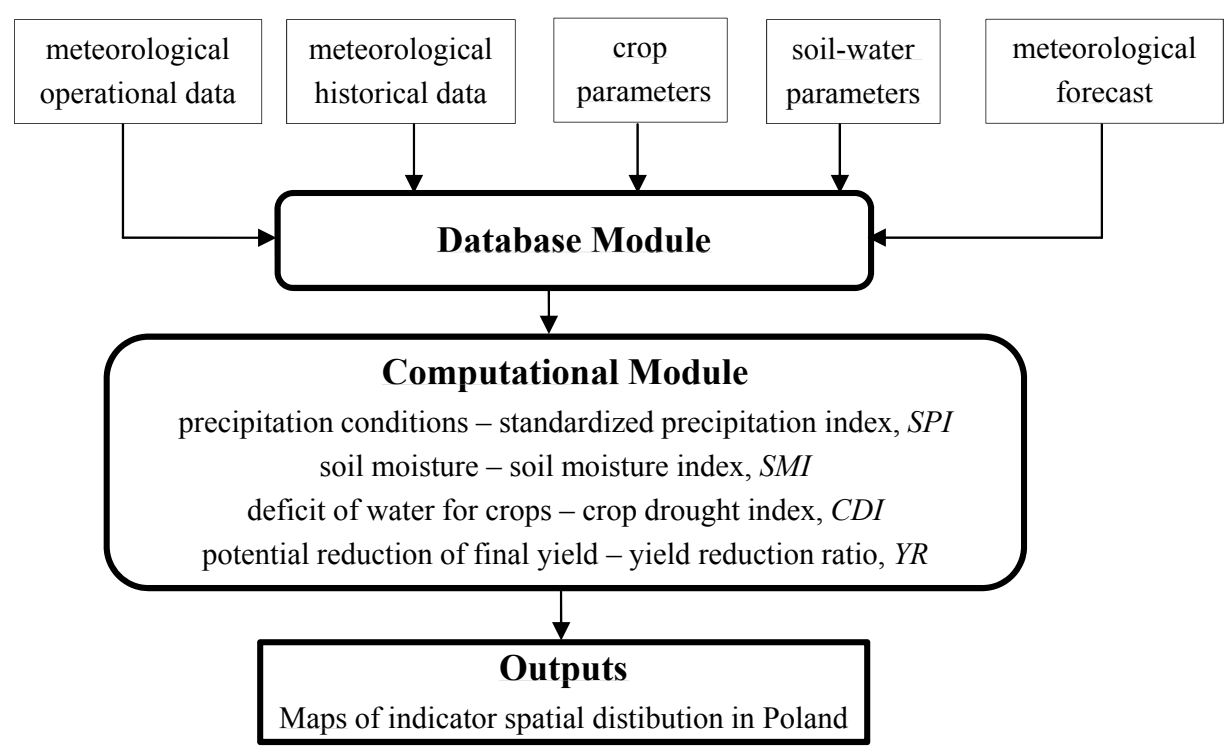

FIGURE 1. System of monitoring and forecasting water deficit and surplus in agriculture in Poland

series of precipitation measurements at different meteorological stations all over the country. Values of SPI for periods longer than one month are calculated for moving totals of precipitation. For each month of the calendar year, a new series is created with the elements equal to corresponding precipitation moving sums. For example, the 3-month SPI calculated for June 2013 utilized the precipitation total of April 2013 through to June 2013 in order to calculate the index. Likewise, the 12-month SPI for June 2013 utilized the precipitation total for July 2012 through to June 2013. Thus, SPI values describe meteorological drought at the end of a month, caused by deviation of precipitation during 1-, 2-, 3-, 6-, 12-, 24-, 36- and 48-month time periods in relation to the median value (values with $50 \%$ probability). Moreover, $S P I-1$ is calculated for the 30/31-day periods moved every 10 days by 10 days.
The SPI calculation for any location is based on the long-term precipitation record in a given period. SPI is calculated using the normalization method. Precipitation is a random variable with a lower limit and often positive asymmetry and does not conform to normal distribution. Most often, periodical (10-day, monthly or annual) sums of precipitation conform to the gamma distribution and, therefore, precipitation sequence is normalized with the transformation function:

$$
f(P)=u=\sqrt[3]{x}
$$

where:

$x$ - element of precipitation sequence.

Values of the $S P I$ for a given $P$ are calculated with the equation:

$$
S P I=\frac{f(P)-\bar{u}}{d_{u}}
$$

where:

$f(P)$ - transformed sum of precipitation, 
$\bar{u}$ - mean value of the normalised precipitation sequence,

$d_{u}$ - standard deviation of the normalised precipitation sequence.

The values of SPI are compared with the boundaries of different classes. Because the SPI is normalized, wet and dry periods can be classified symmetrically. There are many classifications used by different authors. Originally, McKee et al. (1993) distinguished four categories of drought: mild, moderate, severe and extreme, with the threshold value of $S P I$ for the mild drought category equal to $S P I=0$. Agnew (2000) writes that in this classification all negative values of $S P I$ are taken to indicate the occurrence of drought - this means that for $50 \%$ of the time drought is occurring. He concluded that it was not rational and suggested alternative, more rational thresholds. According to Vermes (1998), seven categories were proposed with the first class of a dry period starting at $S P I=-1$ and with the wet period at $S P I=1$.

Within the presented system, the ninecategory classification is used as shown in Table 1.

TABLE 1. Classification of the SPI values and precipitation category used by ITP (http:agrometeo.itp.edu.pl)

\begin{tabular}{|c|l|}
\hline SPI & Period classification \\
\hline$\geq 2.00$ & extremely wet \\
\hline$[1.50 ; 2.00)$ & severely wet \\
\hline$[1.00 ; 1.50)$ & moderately wet \\
\hline$[0.50 ; 1.00)$ & slightly wet \\
\hline$(-0.50 ; 0.50)$ & normal \\
\hline$(-1.00 ;-0.50]$ & slightly dry \\
\hline$(-1.50 ;-1.00]$ & moderately dry \\
\hline$(-2.00 ;-1.50]$ & severely dry \\
\hline$\leq-2.00$ & extremely dry \\
\hline
\end{tabular}

\section{Soil moisture conditions}

Soil moisture index $(S M I)$ is used to evaluate soil moisture conditions and to quantify soil drought intensity. It is calculated as (Hunt et al. 2008):

$$
S M I=-5+10 \frac{A S W_{a}}{T A S W}
$$

where:

$A S W_{a}$ - actual available soil water (mm), $T A S W$ - total available soil water $(\mathrm{mm})$. $A S W_{a}$ and $T A S W$ are calculated by using the calculation procedure presented in the sub-chapter "Calculation methods".

This method is based on an assumption that evapotranspiration (ET) becomes limiting below the midpoint between field capacity and wilting point, or at $50 \%$ of total available water. No reduction in $E T$ occurs until soil water falls below $50 \%$ of field capacity. Below $50 \%$ of field capacity, the reduction in $E T$ is linear.

The four-category classification of soil moisture conditions is used and two categories of soil drought are distinguished within it (moderate and severe drought), with the threshold value for soil drought equal to $S M I=0.00$ (Table 2).

TABLE 2. Classification of soil moisture according to $S M I$

\begin{tabular}{|c|c|}
\hline Soil drought category & $S M I$ \\
\hline No drought - excessive moisture & $\geq 5.00$ \\
\hline No drought - optimal moisture & {$[0.00 ; 5.00)$} \\
\hline Moderate drought & {$[-2.00 ; 0.00)$} \\
\hline Severe drought & {$[-5.00 ;-2.00)$} \\
\hline
\end{tabular}

\section{Crop water deficit}

Assessment of water deficit for crops is made using the crop drought index $(C D I)$, which quantifies agricultural drought intensity (Brunini et al. 2005, Narasimhan and Srinivasan 2005, Tian and Boken 
2005, Łabędzki 2006). It indicates the reduction of evapotranspiration in relation to potential evapotranspiration due to soil water deficit and is calculated as:

$$
C D I=1-\frac{E T}{E T_{p}}
$$

where:

$E T$ - actual evapotranspiration under soil water deficit (mm),

$E T_{p}$ - potential evapotranspiration under sufficient soil moisture content $(\mathrm{mm})$.

$C D I$ assumes the values within the range $\langle 0,1\rangle$ :

- $C D I=0$, when $E T=E T_{p}$,

- $C D I<1$, when $E T<E T_{p}$,

- $C D I=1$, when $E T=0$.

$E T$ and $E T_{p}$ are calculated by using the calculation procedure presented in the sub-chapter "Calculation methods".

To categorize and evaluate the severity of drought, $C D I$ should be compared with the limits of different classes of drought. There is no unique, commonly acceptable classification of agricultural drought according to $C D I$. The three-category drought classification is used (moderate, severe, and extreme drought), with the threshold value for the moderate drought category equal to $C D I=0.1$ (Table 3). It means that a $10 \%$ reduction of evapotranspiration in relation to potential evapotranspiration is not considered as a drought effect.

TABLE 3. Classification of agricultural drought according to $C D I$

\begin{tabular}{|c|c|}
\hline Agricultural drought category & $C D I$ \\
\hline No drought & {$[0.00 ; 0.10)$} \\
\hline Moderate drought & {$[0.10 ; 0.20)$} \\
\hline Severe drought & {$[0.20 ; 0.50)$} \\
\hline Extreme drought & {$[0.50 ; 1.00]$} \\
\hline
\end{tabular}

\section{Crop yield reduction}

Crop yield reduction $(Y R)$ is used to quantify the effect of water stress and agricultural drought on a crop and is calculated from the equation (Raes 2004, Raes et al. 2006):

$$
\begin{aligned}
& Y R=\left(1-\frac{Y_{r e}}{Y_{p}}\right)= \\
& =1-\prod_{i=1}^{N}\left[\prod_{j=1}^{M}\left(1-k_{y}\left(1-\frac{E T}{E T_{p}}\right)\right)_{j}^{\frac{\Delta t_{j}}{L_{i}}}\right]_{i}
\end{aligned}
$$

where:

$Y_{r e}-$ actual yield reduced due to water stress,

$Y_{p} \quad$ - potential yield that can be expected under the given growing conditions for non-limiting water conditions,

$k_{y}-$ yield response factor,

ET -actual evapotranspiration under soil water deficit,

$E T_{p}$ - potential evapotranspiration under non-limiting water conditions,

$N$ - total number of growth stages,

$M$ - number of time steps with length $\Delta t_{j}$ (days) during the growth stage $i$,

$\Delta t_{j}-$ length of the period $j$ in the growth stage $i$ (days),

$L_{i}$ - total length of the growth stage $i$ (days),

$j$ - number of the period in the growth stage $i$.

The three-category drought classification is used (moderate, severe, and extreme drought), with the threshold value for the moderate drought category equal to $Y R=0.1$ (Table 4). It means that a $10 \%$ reduction of crop yield in relation to potential yield is not considered as a drought effect. 
TABLE 4. Classification of agricultural drought according to yield reduction $(Y R)$

\begin{tabular}{|c|c|}
\hline Agricultural drought category & $Y R(\%)$ \\
\hline No drought - small yield loss & {$[0 ; 9)$} \\
\hline $\begin{array}{c}\text { Moderate drought }- \text { moderate yield } \\
\text { loss }\end{array}$ & {$[10 ; 19)$} \\
\hline $\begin{array}{c}\text { Severe drought }- \text { heavy yield loss } \\
\text { Extreme drought - very heavy yield } \\
\text { loss }\end{array}$ & {$[50 ; 100]$} \\
\hline
\end{tabular}

\section{Calculation methods}

The soil-crop parameters required for calculation of the above indices are estimated by using the CROPBALANCE model that has been developed by the Institute of Technology and Life Sciences (Łabędzki 2006, Łabędzki et al. 2008). It is based on the methodology described by Allen et al. (1998).

The actual evapotranspiration is calculated using the crop and water stress coefficient approach. Evapotranspiration $\left(E T^{t}\right)$ in a day $t$ is calculated as:

$$
E T^{t}=k_{s}^{t} k_{c}^{t} E T_{0}^{t}
$$

where:

$k_{s}^{t} \quad$-water stress coefficient (-),

$\boldsymbol{k}_{c}^{t} \quad$ - crop coefficient (-),

$E T_{0}^{t}$ - reference evapotranspiration in a day $t$, according to the Penman-Monteith equation (Allen et al. 1998), $\left(\mathrm{mm} \cdot \mathrm{d}^{-1}\right)$.

Under excellent soil water conditions $k_{s}^{t}=1$ and

$$
E T^{t}=E T_{p}^{t}=k_{c}^{t} E T_{0}^{t}
$$

where:

$E T_{p}^{t}$-potential evapotranspiration in a day $t\left(\mathrm{~mm} \cdot \mathrm{d}^{-1}\right)$.

Reference evapotranspiration $\left(E T_{0}^{t}\right)$ incorporates the effect of weather condi- tions on evapotranspiration. Crop coefficient $\left(k_{c}^{t}\right)$ predicts evapotranspiration under standard conditions, i.e. under excellent agronomic and soil water conditions. The effect of soil water stress on crop evapotranspiration is described by reducing the value of the crop coefficient, and multiplying it by the water stress coefficient $\left(k_{s}^{t}\right)$. The water stress coefficient is calculated as (Allen et al. 1998):

$$
k_{s}^{t}=\frac{A S W_{p}^{t}}{(1-p) T A S W_{r}}
$$

where:

$A S W_{p}^{t}$ - available soil water in the root zone at the beginning of a day $t(\mathrm{~mm})$,

$p$ - soil water depletion fraction, fraction of $T A S W_{r}$ that a crop can extract from the root zone without suffering water stress (Allen et al. 1998), (-), $T A S W_{r}$ - total available soil water in the root zone (mm).

Actual available soil water is calculated from a daily water balance for the root zone:

$$
\begin{aligned}
& A S W_{p}^{t}=A S W_{k}^{t-1}= \\
& =A S W_{p}^{t-1}+P^{t-1}-E T^{t-1}
\end{aligned}
$$

where:

$A S W_{k}^{t-1}, A S W_{p}^{t-1}$ - available soil water

in the root zone at the end and at the beginning of a day $t-1(\mathrm{~mm})$, $P^{t-1}-$ precipitation in a day $t-1(\mathrm{~mm})$, $E T^{t-1}$ - evapotranspiration in a day $t-1$ $(\mathrm{mm})$.

Total available soil water (TASW) is calculated in the $10-\mathrm{cm}$ layers as the difference between the water content at field capacity $(\mathrm{pF}=2.0)$ and wilting point ( $\mathrm{pF}=4.2$ ), using the formula: 


$$
T A S W=S W C_{p F 2.0}-S W C_{p F 4.2}
$$

where:

$S W C_{p F 2.0}, S W C_{p F 4.2}$ - soil water content $(\mathrm{mm})$ at $\mathrm{pF}=2.0$ and $\mathrm{pF}=4.2$, respectively.

$T A S W_{r}$ is calculated in the root zone, changing in time according to the root depth $(d)$.

This simple procedure assumes that the infiltration of daily precipitation to the root zone is within the same day as well as the time of deep percolation from the root zone when soil water content exceeds field capacity, is also one day.

\section{SYSTEM OPERATION}

The SPI values are calculated on the basis of precipitation data from 35 meteorological stations of the Institute of Meteorology and Water Management (IMGW) - National Research Institute (Fig. 2). Series of precipitation records from the period 1961-2013 at each station, are used as historical data.

The SPI is calculated at the 1-, 2-, 3-, 6-, 12-, 24-, 36- and 48-month time scales for each calendar month from January to December and for the 30/31-day periods moved every 10 days by 10 days, on the basis of precipitation data from 35 meteorological stations. Using the forecasted precipitation, predictions of 30-day SPI are created in the next 10 and 20 days. Weather forecasts necessary to develop predictions of water deficit or surplus in the next 10 and 20 days, come from the meteorological service of MeteoGroup Poland (2014). MeteoGroup has developed its own system of forecasting called Multi-Model MOS (Model Output Statistics) which is based on numerical model calculations of the most respected European meteorological centres: the European Centre for Medium-Range Weather

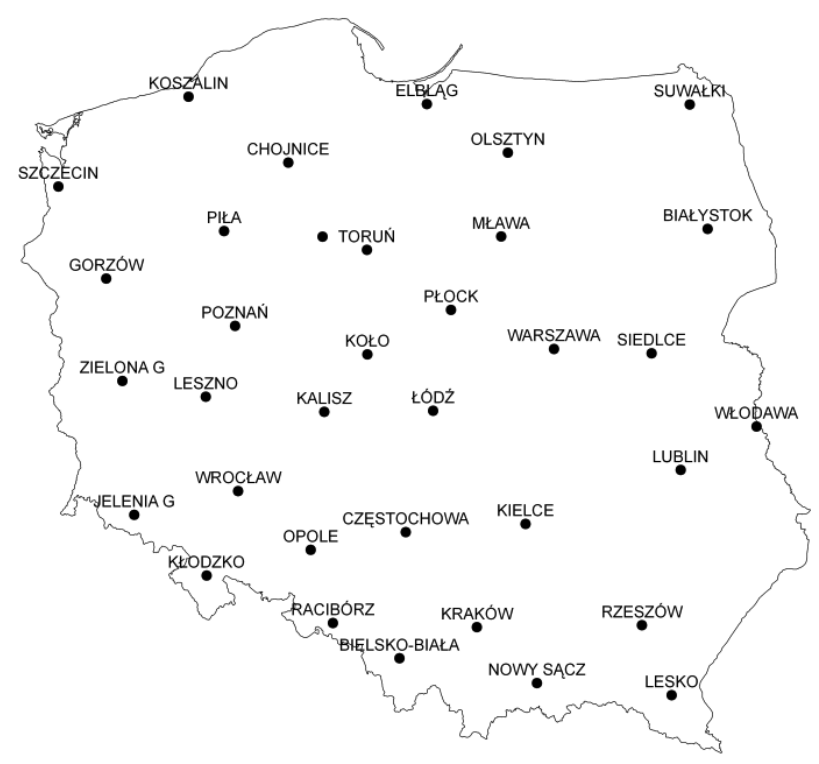

FIGURE 2. Location of meteorological stations in Poland for which SPI is calculated 
Forecasts (ECMWF), the National Centres for Environmental Prediction (NCEP), and the Meteorological Office (Met Office). Forecasted meteorological parameters are: air temperature and humidity, solar radiation, wind velocity and precipitation.

An example of rainfall conditions in June 2013 on the basis of SPI is shown in Figure 3.

Soil moisture (soil moisture index - SMI), deficit of water for crops (agricultural drought index $-C D I$ ) and potential yield reduction $-Y R$ are evaluated every $10 / 11$ days for the previous $10 / 11$ days and forecasted in the next 10 and 20 days. The assessment is done in 13 regions distinguished on the basis of diversity of climate and agroclimatic conditions in Poland (Fig. 4). The total area of the selected region under monitoring is $204,000 \mathrm{~km}^{2}$. The required meteorological data are provided by a network of automatic stations located in these regions. Actual data are transferred to the computational centre at the Kuyavian-Pomeranian Research Centre of ITP using GPRS.

Assessment of soil moisture, crop water deficit and yield reduction is made for selected crops: winter wheat, spring barley, late potato, sugar beet, winter rape, maize on very light, light, medium-heavy and heavy soils; permanent grasslands in wet, moist, periodically dry and dry sites.

The example of the soil moisture conditions $(S M I)$ under late potato on light

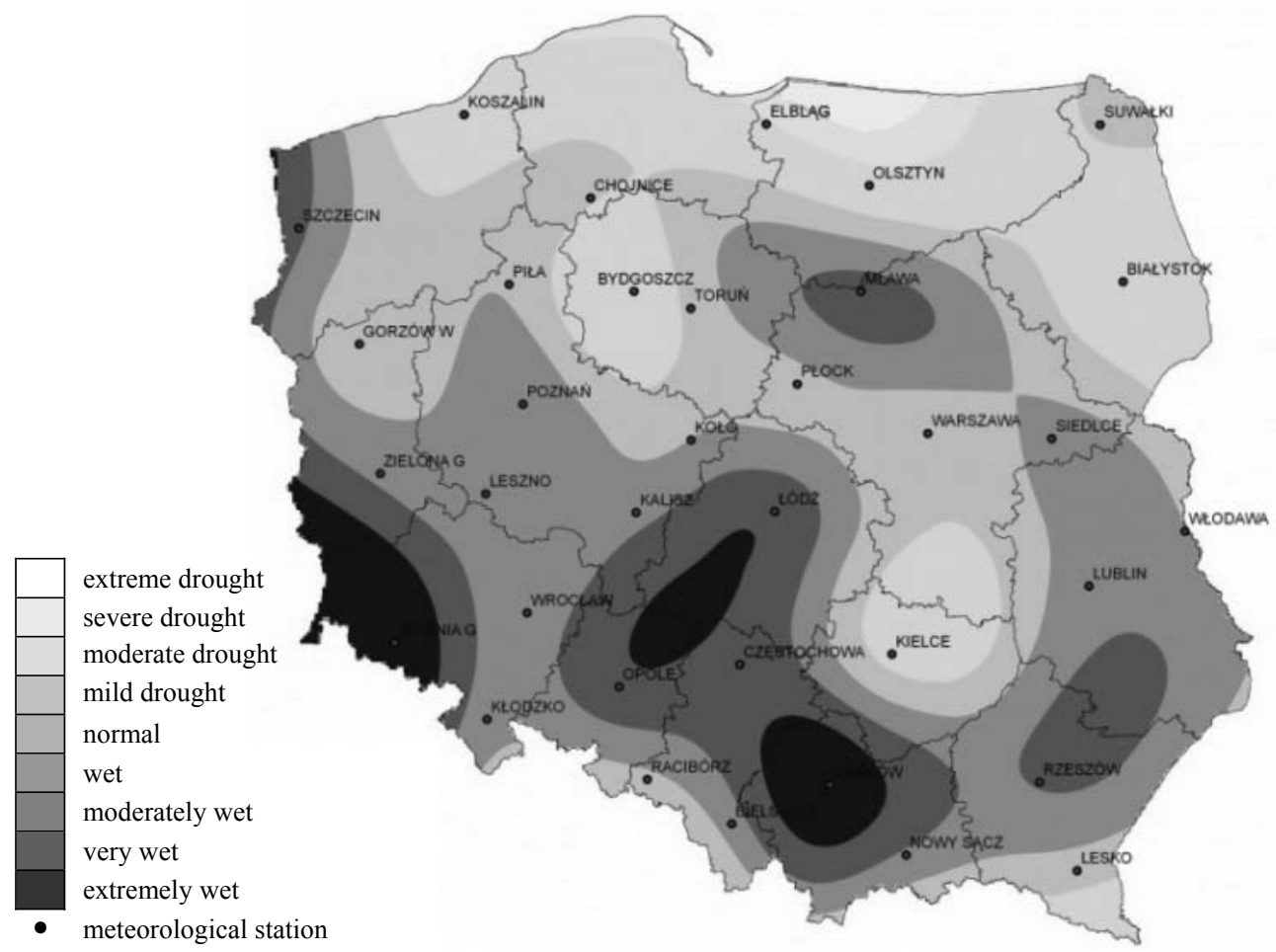

FIGURE 3. Precipitation conditions in Poland in June 2013 according to SPI 


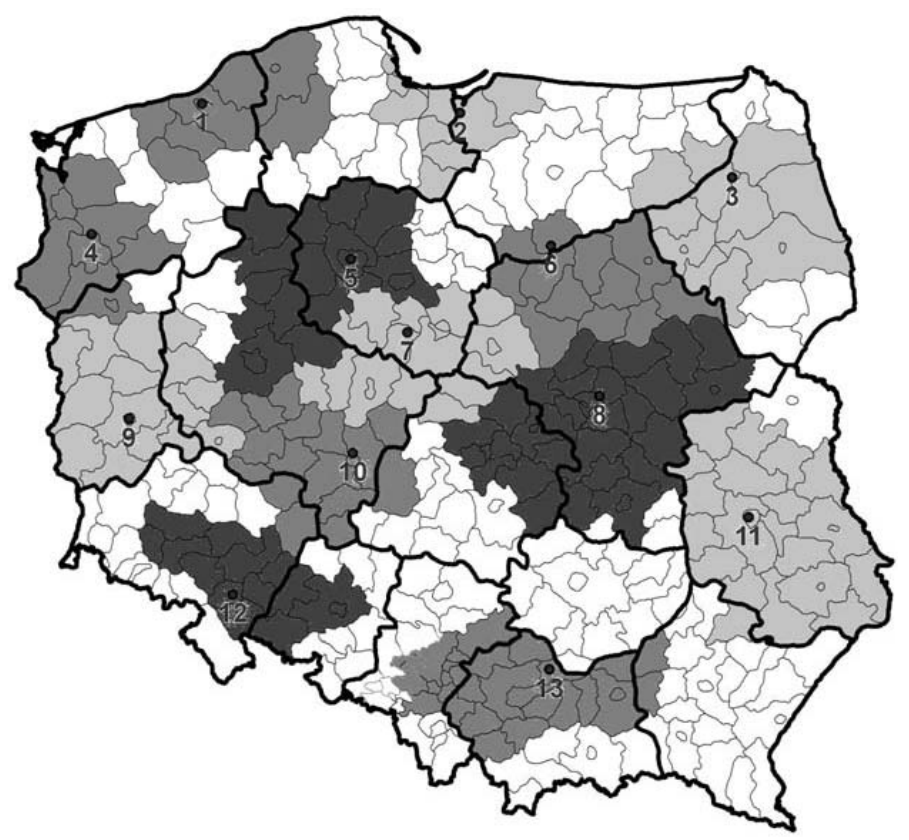

FIGURE 4. Selected agricultural regions and meteorological stations (labelled with number on a figure)

soil in 21-30 June 2013 is shown in sity for grassland and the evaluation of Figure 5. Figures 6 and 7 show the refe- late potato yield reduction on very light rence maps of agricultural drought inten- soils on 10 July 2013.

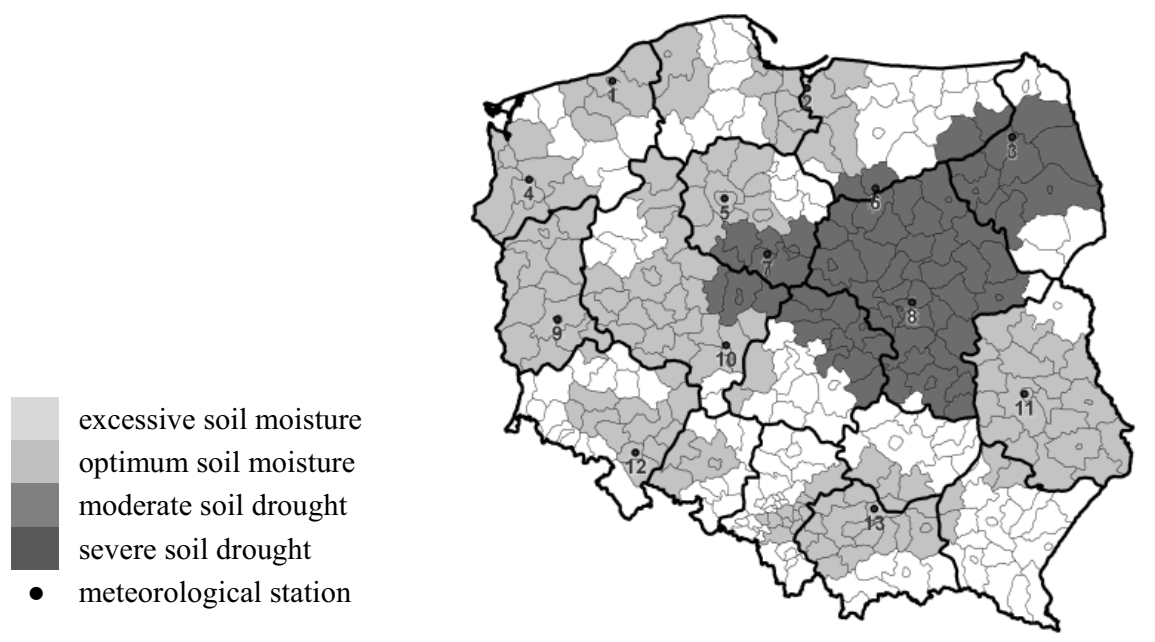

FIGURE 5. Soil moisture conditions in late potato cultivation based on the SMI in the period 21-30 June 2013 on light soil 
Extreme drought

Severe drought

Moderate drought

No drought

- meteorological station

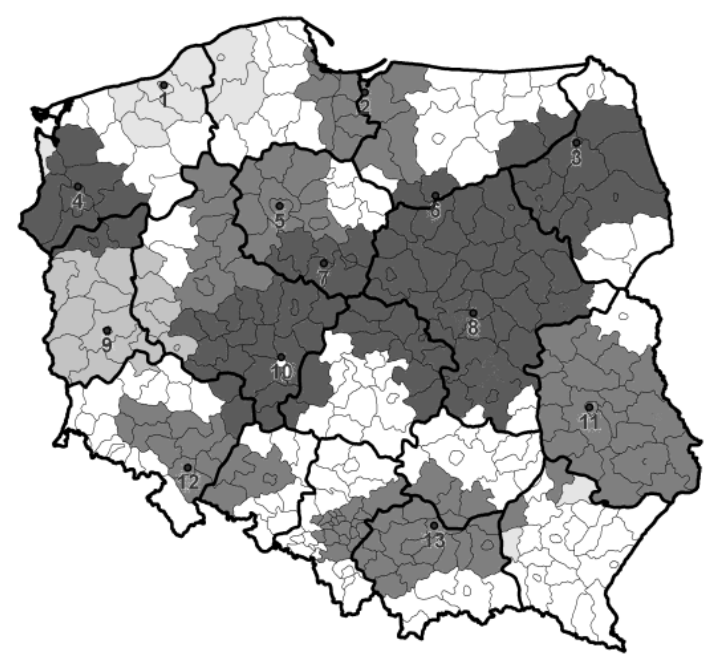

FIGURE 6. Agricultural drought for permanent grassland on the base of $C D I$ in a dry habitat (evaluation on 10 May 2015)
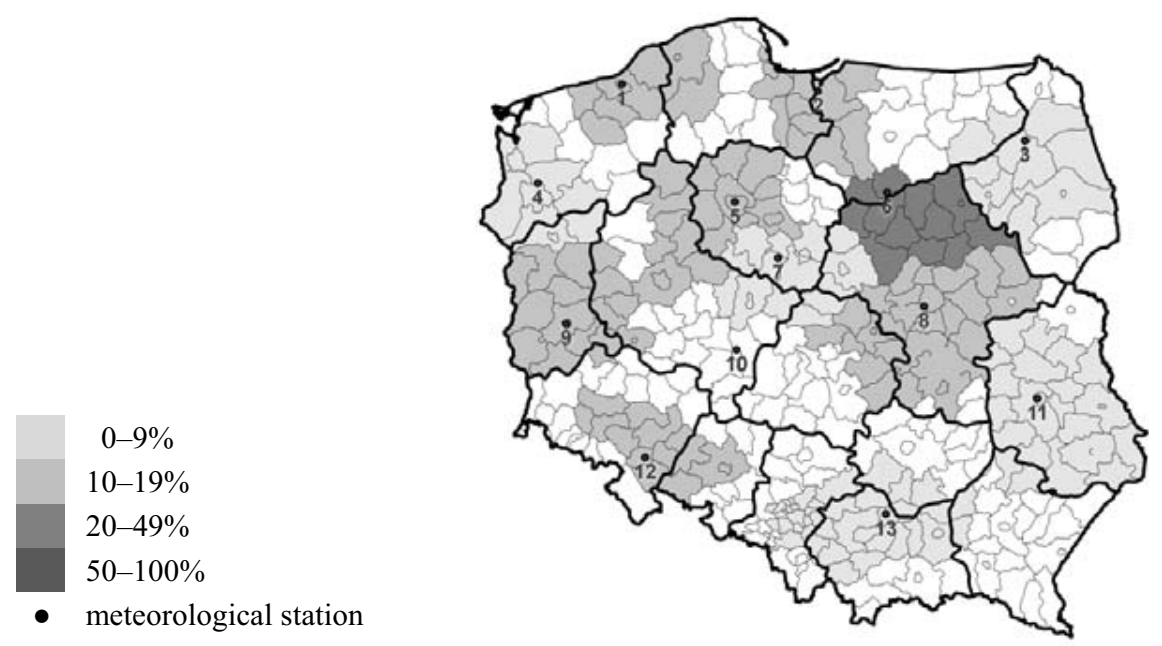

FIGURE 7. Crop yield reduction $Y R$ (\%) of late potato on very light soil (evaluation on 10 July 2013)

\section{CONCLUSIONS}

In regions with large agricultural interests, the monitoring of agrometeorological conditions can be valuable in supporting decision-making in agriculture at the farm or regional level. The Institute of Technology and Life Sciences (ITP) has developed a nationwide system of monitoring and forecasting water deficit and surplus in agriculture. The presented system gives information on precipitation conditions, soil moisture, crop water 
deficit and crop yield reduction, using different indicators. The indicators provide a concise overall measure of the phenomena on the basis of available and easily measured hydro-climatic, soil and crop data.

The preference for particular methods and indices depends on their particular application. For monitoring precipitation conditions, the recently developed standardized precipitation index $(S P I)$ is preferable. This index has a multiple time-scale capability and various other advantages when compared to other indices. It is also recommended by the World Meteorological Organization. For monitoring water deficit or surplus in agriculture, SPI should be combined with real-time monitoring of soil moisture conditions, crop water stress and the evaluation of possible crop yield reduction. For this aim, different methods and indices are applied in the systems depicted. Some of them have gained wide acceptance across Europe and the wider world.

Monitoring agrometeorological conditions using automatic weather stations, wireless networks for data transmission and computer modelling, allows to speed up the process of estimating deficit and excess of water in selected regions and update the website content three times a month. The users of the website service agrometeo.itp.edu.pl are able to obtain information about precipitation conditions in Poland and of soil moisture conditions, quantification of agricultural drought and potential losses in yields in selected rural areas. The system also provides a forecast of the conditions and parameters for the next 10 and 20 days.

The information supplied by the existing monitoring systems can support decision-making and activities leading to mitigation of the negative impacts of droughts, rational use of water resources, irrigation scheduling and other human activities that are connected with the climate.

\section{Acknowledgements}

The authors would like to thank Mrs. Ewa Kanecka-Geszke, Ms. Karolina Smarzyńska and Mr. Tymoteusz Bolewski from the Institute of Technology and Life Sciences, Poland, for their contribution in creating the maps presented in the paper.

The Ministry of Agriculture and Rural Development of the Republic of Poland is greatly appreciated for financing this project within the Programme "Standardization and monitoring of environmental projects, agricultural technology and infrastructure solutions for security and sustainable development of agriculture and rural areas", conducted by ITP in 2011-2015.

\section{REFERENCES}

ALLEN R.G., PEREIRA L.S., RAES D., SMITH M. 1998: Crop evapotranspiration - Guidelines for computing crop water requirements. FAO Irrigation and Drainage Paper 56.

BOCHENEK Z., DĄBROWSKA-ZIELIŃSKA K., CIOŁKOSZ A., DRUPKA S., BOKEN V.K. 2005: Monitoring agricultural drought in Poland. In: V.K. Boken, A.P. Cracknell, R.L. Heathcote (Eds). Monitoring and predicting agricultural drought. Oxford Univ. Press, Oxford, 171-180.

BRUNINI O., DIAS DA SILVA P.L., GRIMM A.M., ASSAD DELGADO E., BOKEN V.K. 2005: Agricultural drought phenomena in Latin America with focus on Brazil. In: V.K. Boken, A.P. Cracknell, R.L. Heathcote (Eds). Monitoring and predicting agricultural drought. Oxford Univ. Press, Oxford, 156-168. 
CACCIAMANI C., MORGILLO A., MARCHESI S., PAVAN V. 2007: Monitoring and Forecasting Drought on a Regional Scale: Emilia-Romagna Region. In: Methods and Tools for Drought Analysis and Management. Water Science and Technology Library 62, 29-48.

DĄBROWSKA-ZIELIŃSKA K., CIOŁKOSZ A. 2007: Zastosowanie zdjęć satelitarnych do monitorowania suszy w Polsce [Application of satellite images for drought monitoring in Poland]. Prz. Geof. 3-4, 161-178 (Engl. summ.).

DOROSZEWSKI A., KOZYRA J., PUDEŁKO R., STUCZYŃSKI T., JADCZYSZYN J., KOZA P., ŁOPATKA A. 2008: Monitoring suszy rolniczej w Polsce [Agricultural drought monitoring system in Poland]. Wiad. Melior. $i$ Łak 1, 35-38 (Engl. summ.).

DOROSZEWSKI A., JADCZYSZYN J., KOZYRA J., PUDEŁKO R., STUCZYŃSKI T., MIZAK K., ŁOPATKA A., KOZA P., GÓRSKI T., WRÓBLEWSKA E. 2012: Podstawy systemu monitoringu suszy rolniczej [Fundamentals of the agricultural drought monitoring system]. Woda-Środowisko - Obszary Wiejskie 12 (2), 77-91 (Engl. summ.).

HUNT E.D., HUBBARD K.D., WILHITE D.A., ARKEBAUER T.M., DUTCHER A.L. 2008: The development and evaluation of a soil moisture index. Int. J. Climatol. 29 (5), 747-759.

LEŚNY J., JUSZCZAK R., RATAJKIEWICZ H., CHOJNICKI B., URBANIAK M., OLEJNIK J. 2007: Possibilities of decision supporting in agriculture with the help of the Wielkopolska Region Internet Based Agrometeorological Information Service. Sci. Rev. Eng. Env. Sci. 3 (37), 39-47.

ŁABĘDZKI L. 2006: Susze rolnicze - zarys problematyki oraz metody monitorowania i klasyfikacji [Agricultural droughts - an outline of problems and methods of monitoring and classification]. Woda - Środowisko - Obszary Wiejskie. Rozpr. Nauk. Monogr. 17 (Engl. summ.).

ŁABĘDZKI L. 2007: Estimation of local drought frequency in central Poland using the standardized precipitation index SPI. Irrigation and Drainage 56 (1), 67-77. DOI: 10.1002/ ird.285.

ŁABĘDZKI L., BĄK B. 2011a: Prognozowanie suszy meteorologicznej i rolniczej w systemie monitorowania suszy na Kujawach i w dolinie górnej Noteci [Predicting meteorological and agricultural drought in the system of drought monitoring in Kujawy and the Upper Noteć Valley]. Infrastruktura $i$ Ekologia Terenów Wiejskich 5, 19-28 (Engl. summ.).

ŁABĘDZKI L., BĄK B. 2011b: System monitorowania suszy na Kujawach [System of drought monitoring in Kujawy Region]. Zeszyty Problemowe Postępów Nauk Rolniczych 561, 109-118 (Engl. summ.).

ŁABĘDZKI L., BĄK B., KANECKA-GESZKE E., KASPERSKA-WOŁOWICZ W., SMARZYŃSKA K. 2008: Związek między suszą meteorologiczną i rolniczą $\mathrm{W}$ różnych regionach agroklimatycznych Polski [Relationship beetween meteorological and agricultural drought in different agroclimatic regions in Poland]. Woda - Środowisko - Obszary Wiejskie. Rozpr. Nauk. Monogr. 25 (Engl. summ.).

McKEE T.B., DOESKEN N.J., KLEIST J. 1993: The relationship of drought frequency and duration to time scales. Proceedings 8th Conf. Applied Climatology, 17-22 January 1993. Anaheim, California, 179-184.

McKEE T.B., DOESKEN N.J., KLEIST J. 1995: Drought monitoring with multiple time scales. Preprints 9th Conf. Applied Climatology, 15-20 January 1995. Dallas, Texas, 233-236.

MARACCHI G., MARTA A.D., TRIOSSI A., ORLANDINI S. 2002: Internet applications for agrometeorological products. Experiences from Europe. Proceedings of the Expert Group Meeting on Internet Applications for Agrometeorological Products, 6-9 May 2002, Washington DC. USA. Available online at: www.wamis.org/tools/dissem/InternetEurope. pdf (accessed 10.02.14).

MIODUSZEWSKI W., SZYMCZAK T., KOWALEWSKI Z. 2011: Gospodarka wodna jako dyscyplina naukowa w służbie rolnictwa [Water management as a scientific discipline serving agriculture]. Woda-Środowisko-Obszary Wiejskie 11 (1), 179-202 (Engl. summ.).

NARASIMHAN B., SRINIVASAN R. 2005: Development and evaluation of soil moisture deficit index (SMDI) and evapotranspiration deficit index (ETDI) for agricultural drought monitoring. Agric. For. Meteorol. 133, 69-88. DOI: 10.1016/j.agrformet.2005.07.012.

RAES D., 2004: BUDGET - a soil water and salt balance model. Reference Manual, Version 
6.0. Available online at: http://www.iupware. be (accessed 03.10.2014).

RAES D., GEERTS S., KIPKORIR E., WELLENS J., SAHLI A. 2006: Simulation of yield decline as a result of water stress with a robust soil water balance model. Agric. Water Manage. 81, 335-357.

ROSSI S., NIEMEYER S. 2010: Monitoring droughts and impacts on the agricultural production: Examples from Spain. In: A. López-Francos (comp.), López-Francos A. (collab.). Economics of drought and drought preparedness in a climate change context. Zaragoza: CIHEAM / FAO / ICARDA / GDAR / CEIGRAM / MARM. Options Méditerranéennes, 952010, 35-40.

STIGTER K., WALKER S., DAS, H.P., HUDA S., DAWEI Z., JING L., CHUNQIANG L., HURTADO I.H.D., MOHAMMED A.E., ABDALLA A.T., BAKHEIT N.I., Al-AMIN N.K.N., YURONG W., KINAMA J.M., NANJA D., HAASBROEK P.D., SUDAN K. 2010: Meeting farmers' needs for agrometeorological services: an overview and case studies. [Second draft of June 2010]. Available online at: http://www.researchgate. net/publication/228402080_Meeting _ farmers'_needs_for_agrometeorological_ services_An_overview_and_case_studies (accessed 12.03.14).

TIAN G., BOKEN V.K. 2005: Monitoring agricultural drought in China. In: V.K. Boken, A.P. Cracknell, R.L. Heathcote (Eds). Monitoring and predicting agricultural drought. Oxford Univ. Press, Oxford, 354-368.

TOKARCZYK T., SZALIŃSKA W. 2013: The operational drought hazard assessment scheme - performance and preliminary results. Arch. Environ. Prot. 39 (3), 61-77. DOI: 10.2478/ aep-2013-0028.
VERMES L. 1998: How to work out a drought mitigation strategy. An ICID Guide. DVWK Guidelines for water management 309.

Streszczenie: Monitoring i prognozowanie niedoboru i nadmiaru wody $w$ rolnictwie $w$ Polsce metoda wskaźnikowq. Od 2012 roku Instytut Technologiczno-Przyrodniczy prowadzi monitoring warunków opadowych w Polsce. System dostarcza aktualnych i prognostycznych informacji w okresie od kwietnia do października z sieci automatycznych stacji pomiarowych zlokalizowanych w 13 regionach Polski. Ocenę warunków opadowych dokonuje się z wykorzystaniem standaryzowanego wskaźnika opadów (SPI) w różnych skalach czasowych, od 1 to 48 miesięcy. Prognoza warunków pogody, niezbędna do prognozowania wskaźników niedoborów lub nadmiarów opadów na obszarze Polski w kolejnych 10 i 20 dniach. jest dostarczana przez serwis meteorologiczny MeteoGroup Poland. Wyniki monitoringu i prognozy są prezentowane w postaci map na stronach internetowych.

Stowa kluczowe: monitoring wody w rolnictwie, wskaźnik standaryzowanego opadu - SPI, wskaźnik wilgotności gleby - SMI, wskaźnik suszy rolniczej - CDI, redukcja plonu roślin uprawnych

\section{MS. received November 2015}

\section{Authors' address:}

Leszek Łabędzki

Instytut Technologiczno-Przyrodniczy

Kujawsko-Pomorski Ośrodek Badawczy

w Bydgoszczy

Glinki 60, 85-174 Bydgoszcz

Poland

e-mail: 1.labedzki@itp.edu.pl 